BUDGETING : Journal of Business, Management and Accounting

Volume 2, Nomor 1, Desember 2020

e-ISSN: 2715-2480

p-ISSN: 2715-1913

DOI : https://doi.org/10.31539/budgeting.v2i1.1226

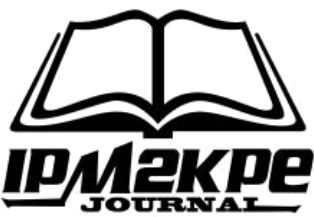

\title{
NILAI PERUSAHAAN BERDASARKAN PRICE EARNING RATIO (PER) DAN GOOD CORPORATE GOVERNANCE (GCG)
}

\author{
Moh. Firman Ardiansyah ${ }^{1}$,Norita Citra Yuliati ${ }^{2}$, Rendy Mirwan Aspirandi ${ }^{3}$ \\ Universitas Muhammadiyah Jember ${ }^{1,2,3}$ \\ pejalankakihitammanis@gmail.com ${ }^{1}$
}

\begin{abstract}
ABSTRAK
Tujuan dari penelitian ini adalah untuk mengetahui apakah terdapat pengaruh Price Earnings Ratio (PER) dan Good Corporate Governance (GCG) dengan proksi (komite audit, komisaris independen, kepemilikan institusional dan kepemilikan manajerial) terhadap nilai perusahaan. Penelitian ini menggunakan metode deskriptif dengan jumlah populasi yang diamati sebanyak 174 perusahaan di Bursa Efek Indonesia periode 20162018. Metode pengambilan sampel yang digunakan adalah teknik purposive sampling. Teknik analisis data yang digunakan dalam penelitian ini adalah analisis regresi linier berganda. Hasil penelitian ini menunjukkan bahwa variabel Price Earning Ratio (PER) secara parsial berpengaruh terhadap nilai perusahaan dan variabel Good Corporate Governance (GCG) yang diproksikan oleh komite audit, komisaris independen, kepemilikan institusional dan kepemilikan manajerial tidak berpengaruh secara parsial terhadap nilai perusahaan manufaktur yang terdaftar di Bursa Efek Indonesia. Simpulan, berdasarkan analisis PER, semakin baik kualitas Investment Opportunity Set (IOS) akan selalu diikuti dengan kenaikan nilai perusahaan. Sedangkan semakin baik kualitas GCG tidak selalu diikuti dengan kenaikan nilai perusahaan.
\end{abstract}

Kata Kunci: Good Corporate Governance, Nilai Perusahaan, Price Earning Ratio

\section{ABSTRACT}

The purpose of this study was to determine whether there is an effect of Price Earnings Ratio (PER) and Good Corporate Governance (GCG) with proxies (audit committee, independent commissioners, institutional ownership and managerial ownership) on firm value. This study uses a descriptive method with a population of 174 companies on the Indonesia Stock Exchange for the period 2016-2018. The sampling method used was purposive sampling technique. The data analysis technique used in this study is multiple linear regression analysis. The results of this study indicate that the variable Price Earning Ratio (PER) partially affects firm value and the variable Good Corporate Governance (GCG) proxied by the audit committee, independent commissioners, institutional ownership and managerial ownership have no partial effect on the value of manufacturing companies listed on the Indonesia Stock Exchange. Conclusion, based on PER analysis, the better the quality of the Investment Opportunity Set (IOS) will always be followed by an increase in company value. Meanwhile, the better the quality of GCG is not always followed by an increase in company value.

Keywords: Price Earning Ratio, Good Corporate Governance, Company Value 


\section{PENDAHULUAN}

Nilai perusahaan yang maksimal merupakan tujuan yang sangat relevan di dalam era persaingan yang sangat ketat ini, terutama untuk perusahaan-perusahaan yang sudah go public (Suripto,2016). Nilai perusahaan merupakan hal yang sangat penting karena dengan nilai perusahaan yang tinggi akan diikuti juga dengan kemakmuran pemegang saham atau pemilik modal (Brigham \& Houston, 2010). Manajemen perusahaan akan berusaha untuk meningkatkan nilai perusahaannya karena dengan meningkatnya nilai suatu perusahaan maka perusahaan akan lebih memiliki kemudahan dalam mendapatkan pedanaan dari pemilik modal karena perusahaan menunjukan kinerja yang baik. Tercapai tidaknya tujuan perusahaan dalam meningkatkan nilai perusahaan dapat dilihat dan diukur dari harga saham perusahaan dari waktu ke waktu (Kasmir, 2010).

Price to Book Value (PBV) didefinisikan sebagai harga pasar suatu saham dibagi dengan nilai bukunya. PBV merupakan rasio yang mengukur nilai yang diberikan pasar keuangan kepada manajemen dan organisasi perusahaan sebagai sebuah perusahaan yang mengalami kinerja yang baik dan terus tumbuh (Brigham \& Houston, 2010). PBV menunjukan seberapa jauh sebuah perusahaan mampu menciptakan nilai perusahaan relatif terhadap jumlah modal yang diinvestasikan.

Rasio atas harga pasar suatu saham terhadap nilai bukunya memberikan indikasi padang investor terhadap perusahaan tersebut (Marlina, 2013). Semakin tinggi PBV semakin baik prospek perusahan tersebut bagi pasar. Perusahaan manufaktur yang mengalami kenaikan berdasarkan nilai PBV-nya adalah sektor barang konsumsi, sektor industri dasar dan kimia dan sektor aneka industri. Pasar modal didalamnya terdapat acuan yang digunakan investor untuk menilai baik tidaknya suatu perusahaan dalam menjalakan usahanya. Acuan yang digunakan ialah nilai perusahaan. nilai perusahaan tercermin dari harga saham di pasar saham.

Nilai perusahaan yang tinggi menjadi keinginan para pemilik modal perusahaan, sebab dengan tingginya nilai perusahaan menunjukan kemakmuran pemegang saham yang tinggi. Pasar modal adalah sarana untuk pembentuk modal dan akumulasi dana yang diarahkan, untuk meningkatkan partisipasi masyarakat dalam pengarahan dana guna menunjang pembiayaan pembangunan nasional (Hartono, 2016). Para investor kini telah banyak menginvestasikan dananya pada perusahaan manufaktur di indonesia 
karena laju perumbuhan pada perusahaan manufaktur ini mengalami kenaikan yang cukup baik.

Fenomena nilai perusahan (PBV) perusahaan manufaktur yang terdaftar di Bursa Efek Indonesia selam periode 2015-2018 dapat dilihat pada gambar 1.

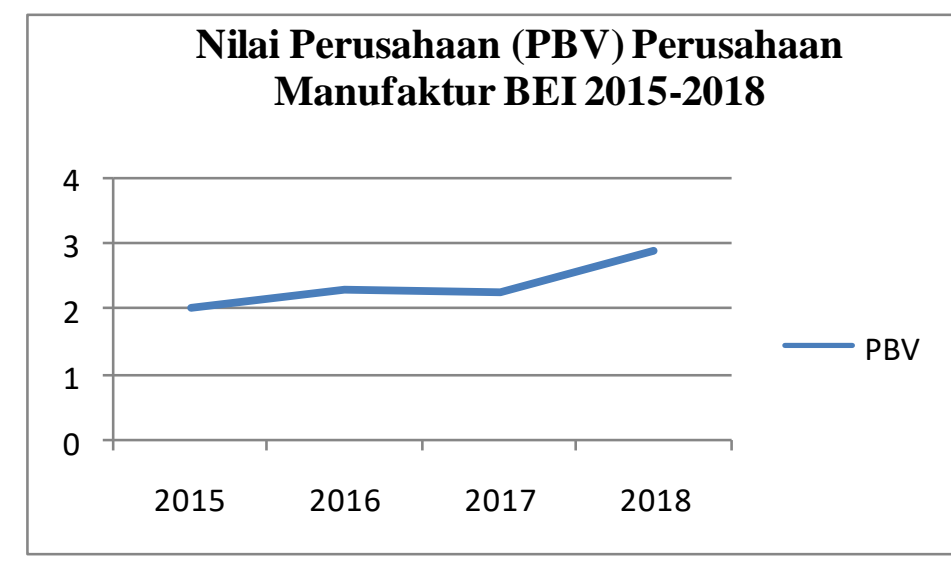

(Sumber: www.idx.co.id, Data Diolah, 2019)

Gambar 1.

Nilai Perusahaan (PBV) Perusahaan Manufaktur BEI 2015-2018

Gambar 1 menunjukan pengerakan nilai PBV perusahaan manufaktur dari tahun 2015 sampai dengan 2018 sangat fluktuatif. Tahun 2015-2016 nilai PBV mengalami kenaikan sebesar 0,27 dari 2,03 ke 2.3. Namun pada tahun 2016 ke 2017 nilai PBV mengalami kenaikan sebesar 0,02 dari 2,3 ke 2,28. Pada tahun 2017 ke 2018 mengalami kenaikan nilai PBV yang signifikan sebesar 0,62 dari 2,28 ke 2,9. Dengan demikian, disimpulkan bahwa nilai perusahaan bisa mengalami kenaikan bahkan penurunan. Kenaikan atau penurunan nilai perusahaan ini dapat dipengaruhi oleh faktor eksternal maupun internal dalam perusahaan sendiri.

Penelitian Price Earning Ratio (PER) dan Good Corporate Governance (GCG) yang diamati dalam satu model untuk melihat pengaruhnya terhadap nilai perusahaan merupakan hasil pengembangan dari penelitian sebelumnya. Berdasarkan hasil penelitian-penelitian sebelumnya, diketahui bahwa masih terdapat inkonsisten. Oleh karena itu, peneliti ingin melakukan penelitian kembali tentang hubungan GCG dan PER terhadap nilai perusahaan yang diukur dengan menggunakan price to book value. Penulis memilih perusahaan manufaktur sebagai objek penelitian. Perusahaan tersebut yang terdiri dari sembilan sektor dan perusahaan manufaktur terdiri dari 3 gabungan 
sektor industri yaitu basic industry and chemical, miscellaneous industry dan consumer goods industry.

\section{KAJIAN TEORI}

\section{Nilai Perusahaan}

Nilai perusahaan adalah nilai jual sebuah perusahaan sebagai suatu bisnis yang sedang beroperasi. Adanya kelibihan nilai jual diatas nilai likuidasi adalah nilai dari organisasi manajemen yang menjalankan perusahaan itu (Sartono, 2010). Nilai perusahaan merupakan kondisi yang telah dicapai oleh suatu perusahaan sebagai gambaran dari kepercayaan masyarakat terhadap perusahaan setelah melalui suatu proses kegiatan selama beberapa tahun, yaitu sejak perusahaan tersebut didirikan sampai saat ini (Noerirawan \& Muid, 2012). Tujuan utama sebuah perusahaan menurut theory of the firm yaitu untuk memaksimalkan kekayaan atau nilai perusahaan (value of the firm) (Salvatore, 2005).

Memaksimalkan nilai perusahaan sangat penting artinya bagi suatu perusahaan karena dengan memaksimalkan nilai perusahaan berarti sama dengan memaksimalkan kemakmuran pemegang saham yang merupakan tujuan utama perusahaan (Hariyadi, 2016). Meningkatkan nilai perusahaan adalah tujuan dari setiap perusahaan, karena semakin tinggi nilai perusahaan maka akan diikuti oleh tingginya kemakmuran pemegang saham. Nilai perusahaan yang tinggi dapat meningkatkan kemakmuran bagi pemegang saham, sehingga para pemegang saham akan menginvestasikan modanlya kepada perusahaan tersebut (Haruman, 2007).

\section{Price Earning Rasio (PER)}

PER merupakan rasio yang mengukur tentang bagaimana investor menilai prospek pertumbuhan perusahaan dimasa yang akan datang dan tercermin pada harga saham yang bersedia dibayar oleh investor untuk setiap rupiah laba yang diperoleh perusahaan (Sudjana, 2009). Menurut Arifin (2004), PER digunakan untuk menilai murah atau mahal sebuah saham, semakin rendah nilai PER sebuah saham maka semakin baik atau murah harganya untuk diinvestasikan. PER adalah rasio yang diperoleh dari harga pasar saham biasanya dibagi dengan laba perusahaan. Maka semakin tinggi rasio akan mengindikasikan bahwa kinerja perusahaan semakin 
membaik. Sebaliknya, jika PER terlalu tinggi maka dapat mengindikasikan bahwa harga saham yang ditawarkan sudah tinggi atau tidak rasional (Sugianto, 2008).

Perusahaan dengan peluang tingkat pertumbuhan tinggi biasanya mempunyai PER yang tinggi. Hal ini menunjukan bahwa pasar mengharapkan pertumbuhan laba di masa mendatang. Sebaliknya perusahaan dengan tinggkat pertumbuhan yang rendah cenderung mempunyai PER yang rendah. PER bisa menjadi rendah karena harga saham cenderung semakin turun atau karena meningkatnya laba bersih perusahaan. Jadi semakin kecil nilai PER maka semakin murah saham tersebut untuk dibeli dan semakinbaik pula kinerja per lembar saham dalam menghasilkan laba bagi perusahaan. Semakin baik kinerja per lembar saham akan mempengaruhi banyak investor untuk membeli saham tersebut.

\section{Good Corporate Governace (GCG)}

Pandangan teori keagenan, terdapat pemisahan antara pihak agen dan prinsipal yang mengakibatkan munculnya potensi konflik dapat mempengaruhi kualitas laba yang dilaporkan. Pihak manajemen yang mempunyai kepentingan tertentu akan cenderung menyusun laporan laba yang sesuai dengan tujuannya dan bukan demi untuk kepentingan prinsipal. Menurut teori keagenan (agency theory) untuk mengatasi masalah tersebut adalah dengan tata kelola perusahaan yang baik (good corporate governance).

Blair (1995) mendefinisikan corporate governance sebagai keseluruhan asset aransemen legal, kebudayaan, dan institusional yang menentukan apa yang dapat dilakukan oleh perusahaan publik, siapa yang mengendalikan, bagaimana pengendalian dilakukan dan bagaimana risiko dan return dari aktivitas-aktivitas yang dilakukan oleh perusahaan tersebutdialokasikan. Cadbury (2000) mendefinisikan corporate governance sebagai keseimbangan antara tujuan ekonomi dan tujuan sosial serta tujuan individu dan tujuan komunitas.

Selain itu, corporate governance juga menekan akuntabilitas dalam pengelolaan segala sumber daya yang memperhatikan seluruh kepentingan, baik individu, perusahaan dan masyarakat. Syakhroza (2002) mendefinisikan corporate governance sebagai suatu sistem yang dipakai oleh board untuk mengarahkan dan mengendalikan serta mengawasi (directing, controlling and supervising) pengelolaan sumber daya 
organisasi secara efisien, efektif, ekonomis dan produktif (E3P) dengan prinsip-prinsip transparan, accountable, responsible, independent dan fairness (TARIF) dalam rangka mencapai tujuan organisasi.

\section{Komite Audit}

Keberadaan Komite Audit diatur melalui Surat Edaran Bapepam Nomor Kep29/PM/2004 (Ketua BAPEPAM, 2004) dan Keputusan Menteri BUMN Nomor KEP103/MBU/2002 (Kementrian BUMN, 2002). Komite audit adalah komite yang dibentuk oleh dewan komisaris dalam rangka membantu melaksanakan tugas dan fungsinya. Komite audit terdiri dari sekurang-kurangnya satu orang komisaris independen dan sekurang-kurangnya dua orang anggota lainnya berasal dari luar emiten atau perusahaan publik. Dalam pelaksanaan tugasnya, komite audit mempunyai fungsi membantu dewan komisaris untuk: a) menilai pelaksanaan kegiatan serta hasil audit yang dilakukan oleh satuan pengawasan intern maupun auditor ekstern sehingga dapat dicegah pelaksanaan dan pelaporan yang tidak memenuhi standar; b) memberikan rekomendasi mengenai penyempurnaan system pengendalian manajemen perusahaan serta pelaksanaannya.

Selanjutnya, c) memastikan bahwa telah terdapat prosedur review yang memuaskan terhadap informasi yang dikeluarkan BUMN, termasuk brosur, laporan berkala, proyeksi/forecast dan lain-lain informasi keuangan yang disampaikan kepada pemegang saham; d) mengidentifikasi hal-hal yang memerlukan perhatian komisaris/dewan pengawas; e) melaksanakan tugas lain yang diberikan oleh komisaris/dewan pengawas sepanjang masih dalam lingkup tugas dan kewajiban komisaris/dewan pengawas berdasarkan ketentuan peraturan perundang-undangan yang berlaku (Bapepam-LK, 2004).

\section{Komisaris Independen}

KNKCG (Komite Nasional kebijakan Corporate Governance), komisaris independen adalah anggota dewan komisaris yang tidak terafiliasi dengan Direks, anggota dewan komisaris lainnya dan pemegang saham pengendali, serta bebas dari hubungan bisnis atau hubungan lainnya yang dapat mempengaruhi kemempuannya untuk bertindak independen atau bertindak semata-mata demi kepentingan perusahaan. 
Keberadaan Komisaris Independen ini berhubungan dengan ketentuan penyelenggaraan tata kelola perusahaan yang baik (GCG).

Boediono (2005) menyatakan bahwa melalui perannya dalam menjalankan fungsi pengawasan, komposisi dewan dapat mempengaruhi pihak manajemen dalam menyusun laporan keuangan sehingga dapat diperoleh suatu laporan laba yang berkualitas. Kusumawati \& Riyanto (2005) menyatakan bahwa jika ternyata investor bersedia membayar lebih mahal, maka nilai pasar perusahaan yang menerapkan good corporate governance juga akan lebih tinggi dibanding perusahaan yang tidak menerapkan atau mengungkapkan praktek good corporate governance mereka.

\section{Kepemilikan institusional}

Jensen \& Meckling (1976) menyatakan bahwa kepemilikan institusional memiliki peranan yang sangat penting dalam meminimalisasi konflik keagenan yang terjadi antara manajer dan pemegang saham. Keberadaan investor institusional dianggap mampu menjadi mekanisme monitoring yang efektif dalam setiap keputusan yang diambil oleh manajer. Hal ini disebabkan investor institusional terlibat dalam pengambilai yang strategis sehingga tidak mudah percaya terhadap tindakan manipulasilaba. Kepemilikan institusional adalah kepemilikan saham perusahaan yang dimiliki oleh institusi atau lembaga seperti perusahaan asuransi, bank, perusahaan investasi dan kepemilikan institusi lain (Tarjo, 2008).

Barnae \& Rubin (2005) menyatakan bahwa institusional shareholders dengan kepemilikan saham yang besar, memiliki insentif untuk memantau pengambilan keputusan perusahaan. Begitu pula penelitian Wening (2009), semakin besar kepemilikan oleh institusi keuangan maka semakin besar pula kekuatan suara dan dorongan untuk mengoptimalkan nilai perusahaan. Menurut Suranta dan Merdistuti (2004) aktivitas monitoring institusi mampu mengubah struktur pengelolaan perusahaan dan mampu meningkatkan kemakmuran pemegang saham. Monitoring yang dilakukan institusi mampu mensubstitusikan biaya keagenan lain sehingga biaya keagenan menurun dan nilai perusahaan meningkat. 


\section{Kepemilikan Manajerial}

Struktur kepemilikan manajerial didefinisikan sebagai kepemilikan saham yang dimiliki oleh direksi, manajer, karyawan dan perangkat internal perusahaan. Kepemilikan manajerial dapat meminimalisir perilaku opportunistic yang dilakukan oleh manajemen (Putri \& Handayani, 2009). Manajer dalam hal ini memegang peranan penting karena manajer melaksanakan perencanaan, pengorganisasian, pengarahan, pengawasan serta pengambilan keputusan (Sukirni, 2012). Kepemilikan manajerial dapat mempengaruhi keputusan pencarian dana melalui utang dan dan tersebut dapat dipergunakan oleh perusahaan untuk melakukan reinvestasi dimasa yang akan datang (Efni, 2013).

Kepemilikan saham oleh manajerial, digunakan untuk menyelaraskan kepentingan antara pemegang saham dan manajemen, ketika semakin besar kepemilikan manajerial, manajer dalam pengambilan keputusan lebih bertindak berhati-hati karena ikut menanggung konsekuensi dari keputusan yang diambil. Semkain kecil kepemilikan manajerial, berarti hanya sendikit pemegang saham yang terlibat dalam mengelolah perusahaan, hal ini dapat menimbulkan masalah keagenan. Kepemilikan manajerial akan mendorong manajemen untuk meningkatkan kinerja perusahaan karena mereka juga memiliki perusahaan. Kinerja perusahaan yang meningkat akan akan meningkatkan nilai perusahaan (Sujoko \& Soebiantoro, 2007). Dalam laporan keuangan, kepemilikan manajerial ditunjukan dengan besarnya presentase kepemilikan saham perusahaan oleh manajer.

\section{Pengaruh Price Earning Ratio (PER) terhadap Nilai Perusahaan}

PER merupakan rasio yang membandingkan harga saham dengan earning per share yaitu laba per lembar saham. PER yang meningkat dapat menggambarkan pertumbuhan perusahaan. Mabruroh et al., (2015), price earning ratio sering digunakan sebagai pengambil keputusan dalam investasi sehingga mampu memberikan sinyal positif mengenai pertumbuhan perusahaan di masa yang akan datang.

Kallapur \& Trombey (2001) menyatakan bahwa PER perusahaan merupakan komponen penting dari nilai pasar. Hal ini disebabkan PER dari suatu perusahaan mempengaruhi cara pandang manajer, pemilik, investor dan kreditor terhadap perusahaan. PER merupakan proyeksi nilai perusahaan yang besarnya bergantung pada 
pengeluaran-pengeluaran yang dilakukan perusahaan dimasa depan (Gaver \& Gaver, 1993). PER memberikan gambaran terhadap investor mengenai sejauh mana perusahaan dapat menghasilkan keutungan dimasa yang akan datang. Hal ini didukung dengan hasil penelitian yang dilakukan oleh Henriansyah dan Dharmayuni (2016) bahwa PER berpengaruh terhadap nilai perusahaan.

\section{Pengaruh Good Corporate Governance (GCG) terhadap Nilai Perusahaan}

Menurut Forum for Corporate Governance in Indonesia (FCGI) (2001), GCG merupakan seperangkat peraturan yang mengatur hubungan pemegang, pengurus (pengelola) perusahaan, pihak kreditur, pemerintah serta para pemegang kepentingan internal dan eksternal lainnya yang berkaitan dengan hak-hak dan kewajiban mengendalikan perusahaan. Tujuan good corporate governance adalah untuk menciptakan nilai tambah bagi semua pihak yang berkepentingan. Susanti (2019), menyatakan bahwa good corporate governace dapat menciptakan nilai tambah karena, dengan menerapakn good corporate governance diharapkan perusahaan akan memiliki kinerja yang baik sehingga dapat menciptakan nilai tambah dan meningkatkan nilai perusahan yang dapat memberikan keutungan bagi para pemegang saham atau pemilik perusahaan.

Wijayanti \& Mutmainah (2012) menganalisis pengaruh GCG terhadap nilai perusahaan dan mendapatkan kesimpulan dalam penelitiannya bahwa GCG berpengaruh terhadap nilai perusahaan. Besarnya variasi dalam pelaksaanaan mekanisme GCG merupakan faktor yang berdampak signifikan untuk meningkatkan nilai pasar saham dari perusahaan. Presepsi investor yang positif investor akan beraksi positif juga terhadap saham perusahaan tersebut sehingga harga saham perusahaan akan meningkat. Perusahaan-perusahaan dapat mengurangi biaya modal dan meningkatkan nilai pasar ketika meningkatkan praktik GCG. 


\section{METODE PENELITIAN}

Jenis penelitian ini adalah penelitian kuantitatif. Penelitian ini menggunakan data sekunder. Data sekunder merupakan data yang diperoleh secara tidak langsung melalui media perantara, baik yang dipublikasikan dan tidak dipublikasikan. Data sekunder dalam penelitian ini berupa laporan tahunan masing-masing perusahaan yang sudah go public di Bursa Efek Indonesia (BEI) tahun 2016-2018 yang diperoleh dari www.idx.co.id. Metode pengumpulan data yang digunakan dalam penelitian ini adalah metode dokumentasi, yaitu teknik pengambilan data dengan cara mengumpulkan, mencatat, mengkaji data sekunder berupa laporan tahunan perusahaan manufaktur di Bursa Efek Indonesia (BEI). Populasi dalam penelitian ini adalah seluruh perusahaan manufaktur yang terdaftar di Bursa Efek Indonesia (BEI) tahun 2016-2018 dengan jumlah perusahaan 174 selama tiga tahun, jadi total populasi adalah 522 annual report.

\section{Operasional Variabel Penelitian}

\section{Variabel Dependen}

Variabel dependen adalah variabel yang dipengaruhi atau yang menjadi akibat karena adanya variabel bebas (Sugiono, 2009). Variabel dependen dalam penelitian ini adalah nilai perusahaan.

\section{Nilai Perusahaan}

Nilai perusahaan diukur dengan Price to Book Value (PBV). Rasio ini menggambarkan seberapa besar pasar menghargai nilai buku saham suatu perusahaan. Rasio ini mengukur nilai yang diberikan pasar keuangan kepada manajemen dan organisasi perusahaan sebagai perusahaan yang terus tumbuh (Brigham \& Houston, 2010).

Price to Book Value $=\frac{\text { Harga Pasar Per Lembar Saham }}{\text { Nilai Buku Per Lembar Saham }}$

\section{Variabel Independen}

Variabel independen adalah variabel yang mempengaruhi atau yang menjadi sebab perubahannya atau timbulnya variabel dependen (Sugiono, 2009). Variabel independen dalam penelitian ini PER dan GCG. 


\section{Price Earning Ratio (PER)}

PER adalah ukuran kinerja saham yang didasarkan atas perbandingan atas harga saham terdapat pendapat per lembar saham (earning per share). PER menunjukkan perbandingan antara closing price dengan laba per lembar saham (Brigham \& Houston, 2010).

$$
\text { PER }=\frac{\text { Closing Price }}{\text { EPS }}
$$

\section{Good Corporate Governance (GCG)}

Pengukuran good corporate governance (GCG) dalam penilitian ini menggunakan proksi yang terdiri dari komite audit, komisaris independen, kepemilikan institusional dan kepemilikan manajerial.

\section{Komite Audit}

Komite audit dalam penilitian ini diukur dengan menggunakan skala rasio melalui presentase anggota komite audit yang berasal dari luar komite audit terhadap seluruh anggota komite audit (Siallagan \& Machfoedz, 2006).

$$
\text { Komite Audit }=\frac{\text { Jumlah Anggota Komite Audit di Luar Perusahaan }}{\text { Jumlah Anggota Komite Audit }}
$$

\section{Komisaris Independen}

Komisaris independen diukur dengan menggunakan persentase jumlah komisaris independen terhadap jumlah total komisaris yang ada dalam susunan dewan komisaris perusahaan (Boediono, 2005).

$$
\text { Komisaris Independen }=\frac{\text { Jumlah Dewan Komisaris Independen }}{\text { Jumlah Anggota Dewan Komisaris }}
$$

\section{Kepemilikan Institusional}

Kepemilikan manajerial diukur menggunakan skala rasio melalui presentase jumlah saham yang dimiliki pihak manajemen dari seluruh modal saham perusahaan yang beredar (Ismiyanti \& Hanafi, 2003).

Kepemilikan Institusional $=\frac{\text { Jumlah Saham Kepemilikan Institusional }}{\text { Jumlah Saham yang Beredar }}$ 


\section{Kepemilikan Manajerial}

Kepemilikan manajerial adalah persentase kepemilikan saham oleh direksi, manajemen, komisaris maupun setiap pihak yang terlibat secara langsung dalam pembuatan keputusan perusahaan. Kepemilikan manajerial dihitung dengan besarnya persentase saham yang dimiliki oleh manajemen.

$$
\text { Kepemilikan Manajerial }=\frac{\text { Jumlah Saham Kepemilikan Manajerial }}{\text { Jumlah Saham yang Beredar }}
$$

\section{HASIL PENELITIAN}

Uji Statistik Deskriptif

Tabel 1.

Hasil Statistik Deskriptif

\begin{tabular}{cccccc}
\hline & N & Minimum & Maximum & Mean & Std.Deviation \\
\hline PER & 132 & $-20,81$ & 87,84 & 15,66 & 17,23 \\
KomAud & 132 & 0,10 & 0,75 & 0,58 & 0,11 \\
KomInd & 132 & 0,24 & 0,50 & 0,38 & 0,08 \\
KepIns & 132 & 0,01 & 1,25 & 0,66 & 0,28 \\
KepMan & 132 & 0,00 & 0,89 & 0,10 & 0,21 \\
NP & 132 & $-0,32$ & 6,50 & 1,40 & 1,43 \\
Valid N (Listwise) & 132 & & & &
\end{tabular}

(Sumber : Data Lampiran 1 yang Diolah, 2020)

Tabel 1 dapat diketahui bahwa jumlah sampel yang digunakan dalam penelitian ini yaitu sebanyak 44 sampel penelitian. Variabel dependen yaitu nilai perusahaan memiliki nilai minimum sebesar $-0,32$, nilai maksimum sebesar 6,50 , memiliki rata-rata (mean) sebesar 1,4032 dan memiliki standar deviasi (simpangan baku) sebesar 1,43. variabel independen yaitu PER memiliki nilai minimum sebesar -20,81, memiliki nilai maksimum sebesar 87,84, memiliki rata-rata (mean) sebesar 15,66 dan memiliki standar deviasi (simpangan baku) sebesar 17,23. Variabel komite audit memiliki nilai minimum sebesar 0,10, nilai maksimum sebesar 0,75, memiliki rata-rata (mean) sebesar 0,58 dan memiliki standar deviasi sebesar 0,11 .

Variabel komisaris independen memiliki nilai minimum sebesar 0,24, nilai maksimum sebesar 0,50, memiliki rata-rata (mean) sebesar 0,3845 dan memiliki standar deviasi (simpangan baku) sebesar 0,08. Variabel kepemilikan institusional memiliki nilai minimum sebesar 0,01 , nilai maksimum sebesar 1,25 , memiliki rata-rata (mean) sebesar 0,66 dan memiliki standar deviasi (simpangan baku) sebesar 0,28. Variabel 
Kepemilikan Manajerial memiliki nilai minimum sebesar 0,00, nilai maksimum sebesar 0,89, memiliki rata-rata (mean) sebesar 0,1045 dan memiliki standar deviasi (simpangan baku) sebesar 0,21.

\section{Analisis Faktor}

Dalam penelitian ini common factor analysis digunakan untuk memperoleh factor score yang merupakan nilai indeks umum dari proksi tunggal yang membentuk variabel GCG. Nilai masing-masing rasio digunakan sebagai proksi GCG dihitung setiap tahun untuk setiap perusahaan sampel dan selanjutnya digunakan data input dalam proses analisis faktor. Layak tidaknya digunakan analisis faktor ini dapat dilihat dari besaran nilai bivariate pearson correlation coefficient (Dadri, 2011).Indeks faktor yang diperoleh selanjutnya akan digunakan sebagai nilai yang mewakili proksi tunggal GCG. Rekapitulasi hasil perhitungan analisis faktor dengan program SPSS 21.0 yang ditampilkan pada tabel 2 .

Tabel 2.

Hasil Common Factor Analysis

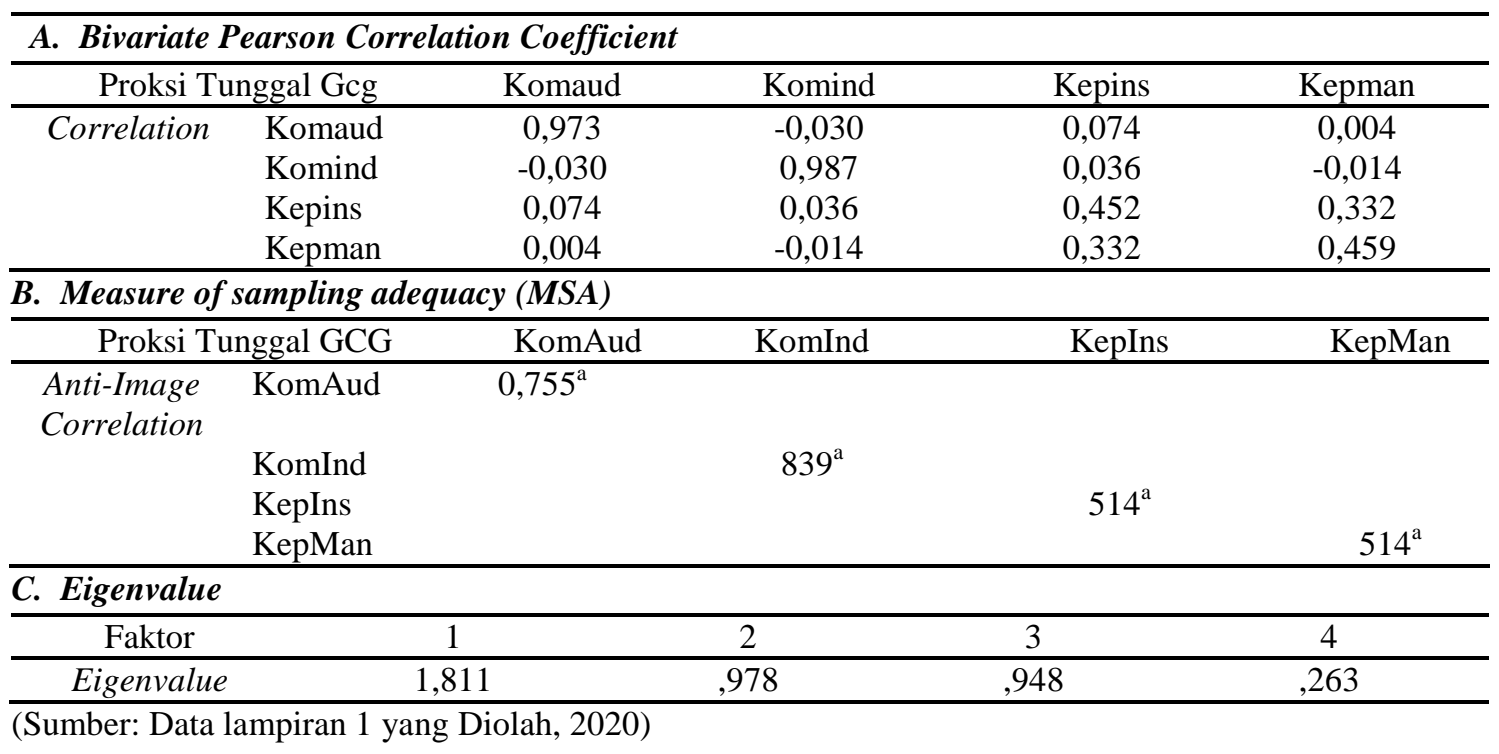

\section{Uji t (Parsial)}

Dalam penelitian ini uji parsial bertujuan untuk melihat pengaruh setiap variabel independen terhadap variabel dependen yang ditujukan pada tabel koefisien. Hasil uji t dalam penelitian ini disajikan dala tabel 3. 
Tabel 3.

Hasil Uji t

\begin{tabular}{cccccc}
\hline Model & \multicolumn{2}{c}{$\begin{array}{c}\text { Unstandardized } \\
\text { Coefficients }\end{array}$} & $\begin{array}{c}\text { Standardized } \\
\text { Coefficients }\end{array}$ & T & Sig. \\
& B & Std. & Beta & & \\
(Constant) & 1,214 & 0,261 & & 4,661 & 0,000 \\
PER (X1) & 0,176 & 0,055 & 0,269 & 3,204 & 0,002 \\
GCG (X2) & $-0,138$ & 0,086 & $-0,135$ & $-1,608$ & 0,110 \\
\hline a. Dependen Variabel: Nilai Perusahaan
\end{tabular}

(Sumber: Data Variabel Nilai perusahaan)

Berdasarkan tabel 3, variabel PER memiliki nilai siginifikan sebesar 0,002. Tingkat signifikansi variabel PER lebih kecil dari alpha 0,05. Hal tersebut menunjukkan bahwa PER berpengaruh terhadap nilai perusahaan.

Variabel GCG memiliki nilai signifikan sebesar 0,110. Tingkat signifikansi variabel GCG lebih besar dari alpha 0,05. Artinya, GCG tidak berpengaruh signifikan terhadap nilai perusahaan.

\section{Uji Koefisien Determinasi $\left(\mathbf{R}^{2}\right)$}

Dalam penelitian ini uji koefisien determinasi bertujuan untuk mengetahui pengaruh antara variabel independen PER dan GCG dengan proksi komite audit, komisaris independen, kepemilikan institusional dan kepemilikan manajerial terhadap variabel dependen (nilai perusahaan). uji koefisien determinasi dalam penelitian ini pada tabel 4 .

Tabel 4.

Hasil Uji Koefisien Determinasi $\left(\mathbf{R}^{2}\right)$

\begin{tabular}{|c|c|c|c|c|}
\hline Model & $\mathbf{R}$ & R Square & Adjusted R Square & Std. Error of the Estimate \\
\hline 1 & $0,298^{\mathrm{a}}$ & 0,075 & 0,323 & 0,10 \\
\hline $\begin{array}{ll}\text { a. } & \text { Pre } \\
\text { b. } & \text { Dep } \\
\end{array}$ & $\begin{array}{l}\text { (constan } \\
\text { Variabel }\end{array}$ & $\begin{array}{l}\text { PER X1, G } \\
\text { ai Perusaha }\end{array}$ & & \\
\hline
\end{tabular}

Hasil uji koefisien determinasi pada tabel 4 menunjukan bahwa nilai Adjusted $\mathrm{R}$ Square sebesar 0,323 artinya variabel dependen (nilai perusahaan) dapat dijelaskan oleh variabel independen (PER dan GCG) sebesar 32\%, sedangkan 68\% dipengaruh oleh variabel lain diluar variabel penelitian ini. 


\section{PEMBAHASAN}

Berdasarkan hasil penelitian, data menunjukkan bahwa PER berpengaruh terhadap nilai perusahaan. Artinya, semakin baik kualitas Investment Opportunity Set (IOS) akan selalu diikuti dengan kenaikan nilai perusahaan. Berbeda dengan hasil penelitian Devianasari \& Suryantini (2015) bahwa PER berpengaruh negatif tidak signifikan terhadap nilai perusahaan Manufaktur di BEI 2009-2013. Keduanya menyatakan bahwa PER dapat berpengaruh positif terhadap nilai perusahaan bersamaan dengan debt to equity ratio, dividen payout ratio.

Hasil analisis GCG pada penelitian ini menunjukkan bahwa tidak adanya pengaruh GCG terhadap nilai perusahaan, yang berarti bahwa semakin baik kualitas GCG tidak selalu diikuti dengan kenaikan nilai perusahaan. Hal ini sejalan dengan hasil penelitian Mutmainah (2015) bahwa GCG berpengaruh negatif secara signifikan terhadap nilai perusahaan pada perusahaan sektor pertambangan yang terdaftar di Bursa Efek Indonesia. Namun, berpengaruh positif dan signifikan terhadap nilai perusahaan bersama dengan Corporate Social Responsibility (CSR).

Menurut Husnan (2006) tujuan utama dibentuknya sebuah perusahaan adalah untuk memaksimalkan nilai perusahaan. Harga yang bersedia dibayar oleh calon investor seandainya suatu perusahaan akan dijual diartikan sebagai nilai perusahaan. Nilai perusahaan yang tinggi menjadi keinginan para pemilik perusahaan, sebab dengan nilai yang tinggi menunjukkan kemakmuran pemegang saham juga tinggi sehingga para pemegang saham akan menginvestasikan modalnya kepada perusahaan tersebut. Untuk mencapai hal tersebut, perusahaan mengharapkan manajer keuangan akan melakukan tindakan terbaik bagi perusahaan dengan memaksimalkan nilai perusahaan sehingga kemakmuran (kesejahteraan) pemilik atau pemegang saham dapat tercapai.

PER merupakan pendekatan yang lebih populer dipakai dikalangan analis saham dan praktisi. Informasi PER mengindikasikan besarnya rupiah yang harus dibayar investor untuk memperoleh satu rupiah earning perusahaan (Tandelilin, 2010). Harga pasar menunjukkan ekspektasi investor tentang laba masa depan dibandingkan dengan laba saat ini (Bhayo et al. 2011)

Menurut Amanti (2012) dengan menerapkan GCG, diharapkan perusahaan akan memiliki kinerja yang baik sehingga dapat menciptakan nilai tambah dan meningkatkan nilai perusahaan yang dapat memberikan keuntungan bagi para pemegang saham atau 
pemilik perusahaan. Secara lebih rinci, terminologi corporate governance dapat dipergunakan untuk menjelaskan peranan dan perilaku dari dewan direksi, dewan komisaris, pengurus perusahaan, dan para pemegang saham.

Penunjang utama sebuah perusahaan untuk melakukan kegiatan operasional agar tujuan perusahaan yang telah ditetapkan dapat tercapai adalah modal kerja (Nugraha, 2013). Keputusan pendanaan keuangan perusahaan sangat menentukan kemampuan perusahaan dalam melakukan aktivitas operasinya. Jika perusahaan meningkatkan porsi hutangnya, maka perusahaan ini dengan sendirinya akan meningkatkan risiko keuangan. Perusahaan juga harus memperhatikan masalah pajak, untuk itu sebagian manajer tidak sepenuhnya mendanai perusahaannya dengan modal sendiri, tetapi disertai penggunaan hutang karena pertimbangan atas manfaat pengurangan pajak yang akan ditimbulkan (Joni \& Lina, 2010).

\section{SIMPULAN}

Price earning ratio (PER) berpengaruh terhadap nilai perusahaan. Berdasarkan hasil tersebut dapat disimpulkan bahwa semakin baik kualitas IOS akan selalu diikuti dengan kenaikan nilai perusahaan. Good corporate governance (GCG) tidak berpengaruh terhadap nilai perusahaan. Berdasarkan hasil tersebut dapat disimpulkan bahwa semakin baik kualitas GCG tidak selalu diikuti dengan kenaikan nilai perusahaan.

\section{DAFTAR PUSTAKA}

Amanti, L. (2012). Pengaruh Good Corporate Governance terhadap Nilai Perusahaan dengan Pengungkapan Corporate Sosial Responsibility sebagai Variabel Pemoderasi (Studi Kasus pada Perusahaan Rokok yang Terdaftar di BEI). Surabaya: Universitas Surabaya

Arifin, A. (2004). Membaca Saham. Yogyakarta: Andi

Badan Pengawas Pasar Modal dan Lembaga Keuangan (Bapepam-LK). (2004). Surat Keputusan Ketua Bapepam. Kep-29/PM/2004 tentang Pembentukan dan Pedoman Pelaksanaan Kerja Komite Audit. Diakses dari http://www.martinaberto.co.id/download/Peraturan_Bapepam/IX.I.5_Pembentuk an_dan_Pedoman_Pelaksanaan_Kerja_Komite_Audit.pdf

Barnae, A., \& Rubin, A. (2005). Corporate Social Responsibility as a Conflict between Shareholders. Jurnal Keuangan dan Perbankan, 16(2), 36-51 
Bhayo, M. U. R., Mubashir, A. K., \& Raja, S. S. (2011). An Idiosyncratic Explanation of Earning Price Ratio Based on Financial Statement Analysis. International Journal of Busisnees and Social Science, 2(9), 243-249

Blair, J. P. (1995). Local Economic Development Analysis and Practice. USA: Sage Publication

Boediono, G. (2005). Kualitas Laba: Studi Pengaruh Mekanisme Corporate Governance dan Dampak Manajemen Laba dengan Menggunakan Analisis Jalur. Simposium Nasional Akuntansi (SNA) VIII. Solo

Brigham, E. F., \& Houston, J. F. (2010). Dasar-Dasar Manajemen Keuangan. Jakarta: Salemba Empat

Cadbury, S. A. (2000). The Corporate Governance Agenda. Corporate Governance an International Review, 8(1), 7-15

Devianasari, N. L., \& Suryantini, N. P. S. (2015). Pengaruh Price Earning Ratio, Debt to Equity Ratio dan Dividen Payout Ratio terhadap Nilai Perusahaan pada Perusahaan Manufaktur yang Terdaftar di Bursa Efek Indonesia. E-Jurnal Manajemen Unud, 4(11), 3646-3674

Sukirni, D. (2012). Kepemilikan Manajerial, Kepemilikan Institusional, Kebijakan Dividen dan Kebijakan Hutang Analisis terhadap Nilai Perusahaan. Accounting Analysis Journal, 1(2), 1-12

Efni, Y. (2011). Analisis Kebijakan Pendanaan, Kepemilikan Manajerial dan Aliran Kas Bebas terhadap Kebijakan Dividen pada Perusahaan Non Manufaktur yang Terdaftar di Bursa Efek Indonesia ( BEI ). Jurnal Ekonomi Universitas Riau, 19(1), 1-12

Forum for Corporate Governance in Indonesia (FCGI). (2001). Peranan Dewan Komisaris dan Komite Audit dalam Pelaksanaan Corporate Governance. Diakses dari http.//www.fcgi.or.id/corporate-governance/articles.html

Gaver, J. J., \& Gaver, K. M. (1993). Additional Evidence on the Association between the Investment Opportunity Set and Corporate Financing, Dividen and Compensation Policies. Journal of Accounting \& Economics, 16(1), 125-160

Hartono, J. (2016). Teori Portofolio dan Analisis Investasi, Edisi Kesepuluh. Yogyakarta: BPFE

Haruman, T. (2007). Pengaruh Keputusan Keuangan dan Kepemilikan Institusional terhadap Nilai Perusahaan, The $1^{\text {st }}$ PPM National Conference on Management Research, Management di Era Globalisasi. Jakarta: Sekolah Tinggi Manajemen

Haryadi, E. (2016). Pengaruh Size Perusahaan, Keputusan Pendanaan, Profitabilitas dan Keputusan Investasi terhadap Nilai Perusahaan. JAK (Jurnal Akuntansi): Kajian Ilmiah Akuntansi, 3(2), 84-100

Henriansyah, G., \& Dharmayuni, L. (2016). Pengaruh Ukuran Perusahaan, Price Earning Ratio dan Profitabilitas terhadap Nilai Perusahaan (Studi Empiris pada Perusahaan Aneka Industri yang Terdaftar di Bursa Efek Indonesia Tahun 20112015). Equity, 20(1), 25-34 
Husnan, S. (2006). Manajemen Keuangan Teori dan Penerapan. Yogyakarta: BPFE Ismiyanti, F., \& Hanafi, H. (2003). Pengaruh Kepemilikan Manajerial, Kepemilikan Institusional, Risiko, Kebijakan Hutang dan Kebijakan Dividen, Analisis Persamaan Simultan. Simposium Simultan Akuntansi. Surabaya

Jensen, M. C., \& Meckling, W. (1976). Theory of the Firm: Managerial Behavior, Agency Cost and Ownership Structure. Journal of Finance Economic, 3(4), 305360

Joni, J., \& Lina, L. (2010). Faktor-Faktor yang Mempengaruhi Struktur Modal. Jurnal Bisnis dan Akuntansi, 12(2), 81-96

Kallapur, S., \& Trombley, M. A. (2001). The Investment Opportunity Set: Determinants, Consequences and Measurement. Managerial Finance, 27(3), 315

Kasmir, K. (2013). Pengantar Manajemen Keuanagan. Jakarta: Kencana Prenada Media Group

Kementerian BUMN. (2002). Keputusan Menteri Badan Usaha Milik Negara Nomor: Kep-103/Mbu/2002 tentang Pembentukan Komite Audit bagi Badan Usaha Milik Negara. Diakses dari http://jdih.bumn.go.id/lihat/KEP-103/MBU/2002

Ketua Badan Pengawas Pasar Modal (BAPEPAM). (2004). Keputusan Ketua Badan Pengawas Pasar Modal Nomor: Kep-29/PM/2004 tentang Pembentukan dan Pedoman Pelaksanaan Kerja Komite Audit. Diakses dari www.ojk.go.id

Kusumawati, D. N \& Riyanto B. L. S. (2005). Corporate Governance dan Kinerja: Analisis Pengaruh Compliance Reporting dan Struktur Dewan terhadap Kinerja. Simposium Nasional Akuntansi VIII. Solo

Mabruroh, V., Riswan, R., \& Lestari, S. (2015). Pengaruh Price Earning Ratio, Leverage, Dividend Payout Ratio, Profitabilitas dan Cash Holding terhadap Nilai Perusahaan pada Perusahaan Non-Keuangan yang Terdaftar dalam Indeks LQ45. Politeknik Tegal Harapan Bersama, 4(1), 82-90

Marlina, T. (2013). Pengaruh Earning Per Share, Return on Equity, Debt to Equity Ratio dan Size terhadap Price to Book Value. Jurnal Ilmiah Akuntansi Kesatuan, 1(1), 59-72

Noerirawan, M. R, \& Muid, A. (2012). Pengaruh Faktor Internal dan Eksternal Perusahaan terhadap Nilai Perusahaan (Studi Empiris pada Perusahaan Manufaktur yang Terdaftar di Bursa Efek Indonesia Periode 2007-2010). Jurnal Akuntansi, 1(1), 582-593

Putri, R., \& Handayani, R. (2009). Pengaruh Kepemlikan Manajerial, Kepemilikan Institusional, Dividen, Pertumbuhan Perusahaan, Free Cash Flow dan Kebijakan Hutang Perusahaan. Jurnal Bisnis dan Akuntansi, 11(3), 189-207

Salvatore, D. (2005). Ekonomi Manajerial dalam Perekonomian Global. Jakarta: Salemba Empat

Sartono, A. (2010). Menejemen Keuangan Teori dan Aplikasi, Edisi 4. Yogyakarta: BPFE 
Siallagan, H., \& Machfoedz, M. (2006). Mekanisme Corporate Governance, Kualitas Laba dan Nilai Perusahaan. Simposium Nasional Akuntansi IX. Padang

Sudjana, S. (2009). Metode Statistika. Bandung: Tarsito

Sugianto, S. (2008). Model-model Pembelajaran Inovatif. Surakarta: Yuma Pustaka

Sugiyono, S. (2009). Metode Penelitian Kuantitatif, Kualitatif dan R\&D. Bandung: Alfabeta

Sujoko, S., \& Soebiantoro, U. (2007). Pengaruh Struktur Kepemilikan Saham, Leverage, Faktor Interen dan Faktor Eksteren terhadap Nilai Perusahan. Jurnal Manajemen dan Kewirausahaan, 9(1), 41-48

Suranta, E., \& Merdistuti, P. P. (2004). Income Smoothing, Tobin's Q, Agency Problem dan Kinerja Perusahaan. Simposium Nasional Akuntansi VII. Denpasar Bali

Suripto, S. (2016). Manajemen Keuangan. Yogyakarta: Graha Ilmu

Susanti, A., Wafirotin, K. Z., \& Hartono, A. (2019). Pengaruh Good Corporate Governance, Profitabilitas dan Ukuran Perusahaan terhadap Nilai Perusahaan Manufaktur yang Terdaftar di BEI Periode Tahun 2011-2016. ISOQUANT: Jurnal Ekonomi, Manajemen \& Akuntansi, 3(1), 11- 24

Syakhroza, A. (2002). Mekanisme Pengendalian Internal dalam Melakukan Assessment terhadap Pelaksanaan Good Corporate Governance. Jurnal Usahawan, 31(8), $41-52$

Tandelilin, E. (2010). Portofolio dan Investasi Teori dan Aplikasi, Edisi Pertama. Yogyakarta: Kanisius

Tarjo, T. (2008). Pengaruh Konsentrasi Kepemilikan Institusional dan Leverage terhadap Manajemen Laba, Nilai Pemegang Saham serta Cost of Equity Capital. Simposium Nasional Akuntansi XI. Pontianak

Wening, K. (2009). Pengaruh Kepemilikan Institusional terhadap Kinerja Keuangan Perusahaan. Diakses dari http://hana.wordpres/2009/05/17/pengaruhkepemilikan-institusionalterhadap-kinerja-keuangan-perusahaan

Wijayanti, S., \& Mutmainah, S. (2012). Pengaruh Penerapan Corporate Governance terhadap Kinerja Keuangan pada Perusahaan Perbankan yang Terdaftar di Bursa Efek Indonesia (BEI) Tahun 2009-2011. Diponegoro Journal of Accounting, 1(2), 1-1 